\title{
Gamification of Urban Development Strategies: Facilitating Understanding of Stakeholder Roles and Strategies
}

\section{Bart Neuts}

To cite this article: Bart Neuts (2020): Gamification of Urban Development Strategies: Facilitating Understanding of Stakeholder Roles and Strategies, SCHOLE: A Journal of Leisure Studies and Recreation Education

To link to this article: https://doi.org/10.1080/1937156X.2020.1718034

\section{曲 Published online: 04 Feb 2020.}

Submit your article to this journal $\widetilde{x}$

Q View related articles $\sqsubset$

View Crossmark data $\asymp$ 


\title{
Gamification of Urban Development Strategies: Facilitating Understanding of Stakeholder Roles and Strategies
}

\author{
Bart Neuts \\ Auckland University of Technology
}

\begin{abstract}
Cities are multifunctional entities, catering to diverse activities and populations. As a result, urban redevelopment strategies often carry important externalities and inclusive processes should be established to move from a traditional planned city to a co-productive city. The following article presents a gamification exercise as a learning activity for a course in Tourism Planning and Development. Game-elements have increasingly been included in consultation rounds as tools to improve co-creation, inclusivity, creativity, and general stakeholder support. The proposed game allowed students to increase their understanding of power-processes and stakeholder strategies, and adapt to other player goals due to the need to gather broad democratic support. Through the game, students became active participants in the creative process of redeveloping city spaces rather than purely critiquing existing plans as passive observers.
\end{abstract}

\section{KEYWORDS}

Development; gamification; immersive learning activity; planning; stakeholder analysis

\section{Introduction and theoretical foundations}

Given the economic importance of tourism for many urbanized areas, an increasing number of cities are specifically including urban tourism within their entrepreneurial approaches, merging visitor functions with residential, commercial, and industrial developments. Due to the financial requirements of large-scale redevelopments and economically constrained public resources, the entrepreneurial approach generally entails close collaboration with a select number of preferential partners-likely real-estate companies-either as fully private parties or via public-private partnerships (Crossa, 2009; Neuts, Devos, \& Dirckx, 2014; Reuschke, 2002). Such cooperation might, however, obscure the preferences of diffuse groups of external stakeholders and increase the complexity of balancing multiple urban functionalities within specific areas. The rising attention to issues of overtourism in various cities is exemplary of the, at times, troubled relationship between visitors and residents-specifically in the case of uneven cost-benefit spread (e.g., Schofield, 2011) - and the inadequacy of pure top-down planning approaches. The latter aspect is discussed by Boley, McGehee, Perdue, and Long (2014) who note how residential empowerment can help to offset negative resident perceptions.

The importance of stakeholder involvement is generally acknowledged in tourism planning literature, recognizing tourism destinations as networks of interdependent actors and the tourist experience as a complex outcome of the interaction with a wide range of destination attributes (Cooper, Scott, \& Baggio, 2009; Waligo, Clarke, \& Hawkins, 2015). While local governments have a prerogative over spatial (re)development processes, both as primary construction partners and as policymakers-establishing boundaries and defining acceptability of building volumes and functions-and large real-estate developers and landowners can influence proceedings due to their 
financial muscle, a further democratization process toward inclusive planning and development is warranted in order to signal potential issues and stakeholder conflicts ex ante (Loopmans \& Marrécau, 2016). Van Herzele (2004) notes that while planning is typically dominated by scientific and expert knowledge that might be lacking in the wider community, local communities often have a more site-specific, experience-based understanding of a space. This is corroborated by Tan (2014), who states that even though large-scale urban transformations, requiring fast turnover, might not lend themselves to a complete inclusion of all stakeholders involved, a sustainable consensus depends on the creation of a collective narrative and vision and a minimization of stakeholder conflicts. The author also remarks how the communication revolution has helped to pave the way for more collaborative urban processes, transforming the twentieth century "planned city" into a self-organizing and co-productive city. However, while the theoretical case for stakeholder inclusion is easily made, examples of top-down planning and poor implementation of stakeholder perspectives are found throughout the tourism planning literature (e.g., Dodds \& Butler, 2010; Getz \& Timur, 2005; Hamilton \& Alexander, 2013; Ioannides, 1995; Ripp \& Rodwell, 2018).

Typically, even a top-down planning process includes consultation rounds and hearings, while also offering residents the chance for objecting in writing within a specified period. Such feedback moments, however, while satisfying legal requirements, remain rather static and one-directional, not offering the best framework for fruitful confrontation of multiple visions (Innes \& Booher, 2004). Recently, consultancy companies in particular have started to adopt more interactive and direct participatory methods in the form of games (see e.g., Tan, 2014), known under the term "gamification". Gamification can take the form of computer games or more traditional non-digital games (e.g., board games, role-play games) and involves the use of game design elements in a non-game context (Deterding, Dixon, Khaled, \& Nacke, 2011). The basic idea in urban development games is to bring together various stakeholders of a development project and by engaging them with a rule-based development game, making them navigate the intricacies, thought-processes and power balances at play to come to a shared vision, developed through grassroots participation.

Such games have furthermore found their way into a classroom teaching context. As pedagogical devices, games have been found to encourage collaborative problem solving, incorporate peer learning, induce creative divergent thinking, and appeal to different learning styles (Boyle, 2011; Jaffe, 2007). Han (2015) discusses how gamification as pedagogy is best suited to a spiral curriculum because of its ability to revisit topics and incrementally increase difficulty, with previous learning complementing new learning. For a game to succeed as educational tool, it needs to include essential aspects such as challenges, narratives and other players (Han, 2015), while the game designer should also set up the process in such a way that all four stages of Kolb's (1984) experiential learning model are covered. These four stages involve: (a) concrete learning via encountering new experiences, (b) reflective observation of the experience on a personal basis, (c) abstract conceptualization where new ideas are formed, or existing abstract ideas are modified based on previous reflection, and (d) active experimentation by applying the ideas to the learner's surroundings. The New London Group (1996) has stated how games could complement instructivist pedagogies by providing a situated practice that lays the foundation for an exploration of abstract concepts through educator-led discussion. Francis (2006) also mentions this need to make students critically reflect on the game learning experience in order for the required knowledge not to remain tacit. The educator plays an important role here in leading such discussion and guiding students through a collaborative process of co-constructing knowledge.

\section{The learning activity}

As part of an undergraduate course in Tourism Planning and Development, 30 students were required to participate in a 2-hour gamification-session, which was designed to help students get 


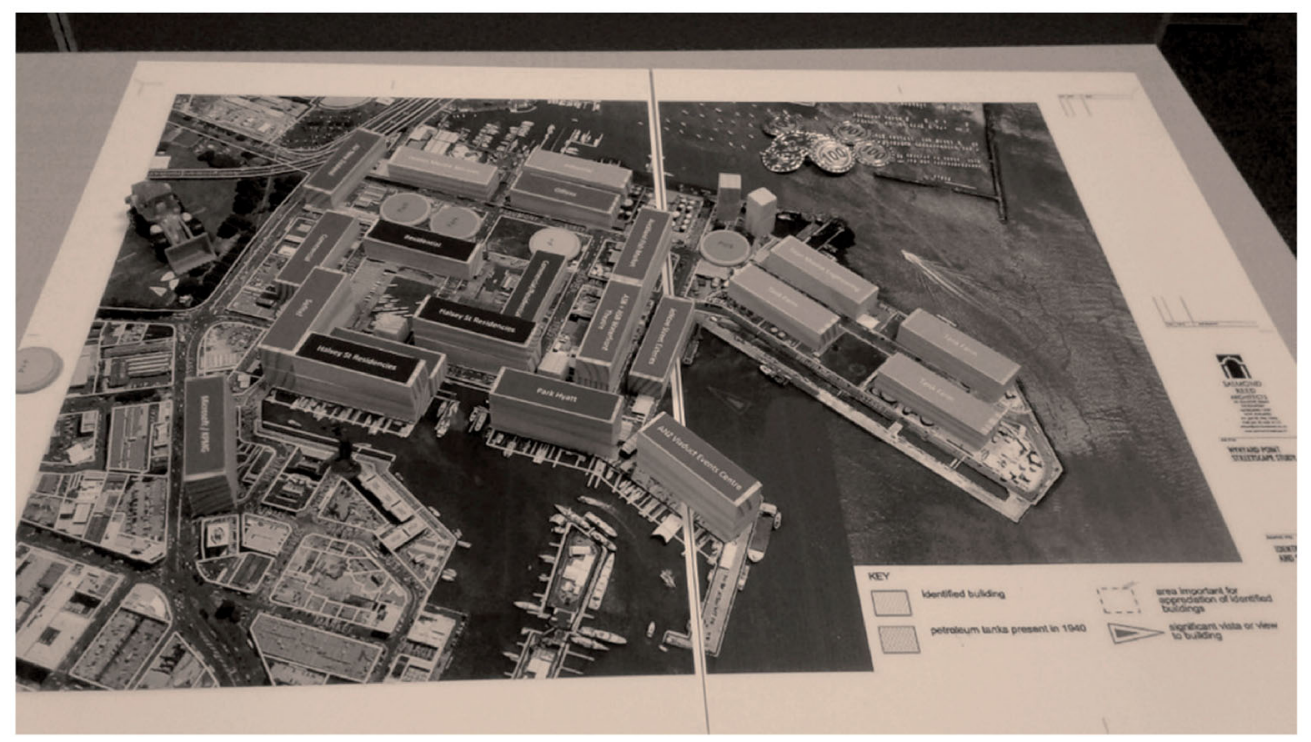

Figure 1. Game board and initial setup.

a better understanding of the redevelopment plans of an area in the city. The assignment required students to take on the role of one of various stakeholders. Depending on the assigned role, students were involved in activities such as: presenting long-term development plans, discussing site proposals, building infrastructure according to budget and zoning plans, protesting plans, and voting. Different roles came with different, unique constraints (e.g., financial, democratic, zonal). As such, the gamification-exercise can lead to a broader understanding of stakeholder views, planning and development constraints, and a more inclusive planning process. The following part outlines each aspect of the gamification exercise, starting with the pre-game design stage.

\section{Pre-game design stage: the game library}

Before the activity could be conducted in a classroom setting, decisions needed to be made on the scenario and game rules, and the game board and pieces needed to be constructed. We chose Wynyard Quarter in Auckland as the game setting. This area had several advantages: (a) being reasonably close to the university, students have at least limited experience with the neighborhood; (b) the area is modest in size, decreasing the game's complexity; (c) the council is the major landowner; and (d) the quarter is still relatively undeveloped and is one of the focal points of a large-scale waterfront redevelopment plan. Due to these characteristics, students could engage with a realistic and meaningful scenario.

A map of the chosen quarter was printed on a 1:2000 scale and served as the main game board (see Figure 1). Seven main stakeholders were identified. For each of these, a different scenario with specific strategies and winning and losing conditions was created (summarized in Table 1). Broadly speaking, a distinction was made between two broad types: stakeholders who are primary drivers behind the redevelopment effort and have financial means and/or land ownership, and stakeholders that have an interest in the plans but whose power is limited to public actions, voting, and/or opinion making. A "visitor" stakeholder group was not specifically included since such temporary residents are more difficult to directly incorporate in a long-term planning context. The potential impact of visitors was, however, an element to be taken into account, specifically relating to the magnitude of potential tourist attractions. The official waterfront redevelopment plan (Waterfront Auckland, 2012) inspired the different scenarios, since it 
Table 1. Summary of stakeholder groups.

\begin{tabular}{|c|c|c|c|}
\hline Description & Instrument & Win & Lose \\
\hline Wynyard Quarter residents & 2 votes per round & $\begin{array}{l}\text { Council takes into account } \\
\text { concerns about a huge } \\
\text { visitor attraction and } \\
\text { accessibility by car } \\
\text { remains possible }\end{array}$ & $\begin{array}{l}\text { A huge visitor attraction is } \\
\text { combined with public } \\
\text { parking allotment that } \\
\text { would increase local traffic }\end{array}$ \\
\hline Residents of greater Auckland & 6 votes per round & $\begin{array}{l}\text { Council takes into account } \\
\text { wishes for a public } \\
\text { parking and tank farm } \\
\text { area will be transformed } \\
\text { in a commercial and } \\
\text { recreational space }\end{array}$ & $\begin{array}{l}\text { Car access becomes } \\
\text { prohibited and tank farm } \\
\text { area will be completely } \\
\text { transformed into an } \\
\text { urban park }\end{array}$ \\
\hline Auckland council & $\begin{array}{l}\text { NZ\$190 } \\
\quad \text { million + land ownership }\end{array}$ & $\begin{array}{l}\text { A majority agreement is } \\
\text { reached, and a private } \\
\text { partner is found to } \\
\text { construct a new stadium } \\
\text { or other visitor attraction } \\
\text { at tank farm }\end{array}$ & $\begin{array}{l}\text { A majority of residents votes } \\
\text { against the council }\end{array}$ \\
\hline Political opposition & None & $\begin{array}{l}\text { A majority of residents votes } \\
\text { for the opposition }\end{array}$ & $\begin{array}{l}\text { The majority of residents } \\
\text { supports the vision } \\
\text { developed by the council }\end{array}$ \\
\hline Ngāti Whātua Ōrākei & 1 vote per round & $\begin{array}{l}\text { A majority of residents } \\
\text { agrees that a stadium } \\
\text { should be built but that it } \\
\text { should be situated on the } \\
\text { grounds near Spark Arena } \\
\text { (owned by you) }\end{array}$ & $\begin{array}{l}\text { The majority of residents } \\
\text { either votes against a new } \\
\text { stadium or wants to see } \\
\text { the stadium appear in } \\
\text { Wynyard Quarter }\end{array}$ \\
\hline Project developers & NZ\$1.5 billion & $\begin{array}{l}\text { Agreement is reached with } \\
\text { the council to go ahead } \\
\text { with the building of a } \\
\text { new stadium, either at } \\
\text { tank farm or near Spark } \\
\text { Arena, with a maximum } \\
\text { private cost of } 500 \\
\text { million NZ\$ }\end{array}$ & $\begin{array}{l}\text { The stadium does not } \\
\text { get built }\end{array}$ \\
\hline Commercial operators & 1 vote per round & $\begin{array}{l}\text { The council takes into } \\
\text { account wishes for public } \\
\text { parking and the tank farm } \\
\text { area will give rise to a } \\
\text { stadium or large-scale } \\
\text { visitor attraction }\end{array}$ & $\begin{array}{l}\text { No public parking is built, } \\
\text { and the tank farm area } \\
\text { will be completely } \\
\text { transformed into an } \\
\text { urban park }\end{array}$ \\
\hline
\end{tabular}

sets out the vision of Auckland council: transforming Wynyard Quarter into a mixed residential, retail, and commercial district, while keeping links to the marine and fishing industries that are particularly prevalent on the eastern edge of the area.

The plans also mention the possibility of developing an unspecified signature public building on the north edge, currently occupied by the tank farm, an industrial zone. This was incorporated into the scenarios with specific mention of the possibility to develop a sports stadium at tank farm, following recent media attention (1news, 2016; Orsman, 2017). The interest in a signature sports stadium from city-branding perspective and for commercial operations could then be juxtaposed with the need for a livable residential environment and allowed for an inclusion of different perspectives on the topic. The budgets that were made available to the Auckland council and project developers was based on actual forecasted budgets (Waterfront Auckland, 2012). Importantly, the budget of the council is insufficient for the realization of its vision, necessitating cooperation with the private sector. Potential tools are public-private partnerships and/or offering council-held land free of charge for projects that fit the general vision.

Students were randomly assigned to one of the stakeholder groups and received their specific character card and a game manual 5 days before the assignment. Importantly, each stakeholder group came with its own development preferences, strategies to achieve the goals, and constraints 
Table 2. Game library-buildings.

\begin{tabular}{|c|c|}
\hline Building description & Price (NZ\$) \\
\hline $\begin{array}{l}\text { Empty land. Land that hasn't been built on, can be used for construction. If land is under ownership of } \\
\text { the player (specifically for the council), the land can be used for free. Otherwise it needs to be bought. }\end{array}$ & 10 million \\
\hline $\begin{array}{l}\text { Urban park. Every park tile is approximately } 1.5 \text { acres in size (about } 6000 \mathrm{~m}^{2} \text { ). Multiple tiles can be } \\
\text { combined to create a larger park. }\end{array}$ & 5 million \\
\hline $\begin{array}{l}\text { Above-ground carpark. This tile offers a single-deck above-ground parking of } 1.5 \text { acres and fitting } 200 \\
\text { cars. Multiple tiles can be combined to create a larger parking. }\end{array}$ & 0.5 million \\
\hline $\begin{array}{l}\text { Underground carpark. This tile offers a single-level, fully underground carpark of } 1.5 \text { acres and fitting } 200 \\
\text { cars. Multiple tiles can be placed on top of each other to create extra underground levels. Building can } \\
\text { be constructed on top of these tiles. }\end{array}$ & 10 million \\
\hline $\begin{array}{l}\text { Multi-storey carpark. This tile offers a multi-storey carpark of } 2 \text { levels below surface and } 3 \text { levels above } \\
\text { surface. It occupies } 1.5 \text { acres of land and can fit } 1000 \text { cars. }\end{array}$ & 30 million \\
\hline $\begin{array}{l}\text { Office block. This block offers a 2-storey office building, occupying } 1 \text { acre (approximately } 4000 \mathrm{~m}^{2} \text { ). } \\
\text { Multiple blocks can be placed on top of each other to create extra storeys. }\end{array}$ & 60 million \\
\hline $\begin{array}{l}\text { Commercial block. This block offers a } 2 \text {-storey commercial building, occupying } 1 \text { acre (approximately } 4000 \\
\mathrm{~m}^{2} \text { ). Multiple blocks can be placed on top of each other to create extra storeys. }\end{array}$ & 60 million \\
\hline $\begin{array}{l}\text { Residential block. This block offers a 2-storey residential building, occupying } 1 \text { acre (approximately } 4000 \\
\mathrm{~m}^{2} \text { ). Multiple blocks can be placed on top of each other to create extra storeys. }\end{array}$ & 60 million \\
\hline $\begin{array}{l}\text { Industrial block. This block offers a } 2 \text {-storey industrial building, occupying } 1 \text { acre (approximately } 4000 \mathrm{~m}^{2} \text { ). } \\
\text { Cannot be combined with other blocks. }\end{array}$ & 40 million \\
\hline $\begin{array}{l}\text { Shared Offices/Residential block. This block offers a 2-storey building, occupying } 1 \text { acre (approximately } \\
4000 \mathrm{~m}^{2} \text { ). The first floor consists of offices while the second floor consists of residential apartments. } \\
\text { Multiple blocks can be placed on top of each other to create extra storeys. }\end{array}$ & 60 million \\
\hline $\begin{array}{l}\text { Shared Commercial/Residential block. This block offers a 2-storey building, occupying } 1 \text { acre } \\
\text { (approximately } 4000 \mathrm{~m}^{2} \text { ). The first floor consists of commercial establishments while the second floor } \\
\text { consists of residential apartments. Multiple blocks can be placed on top of each other to create } \\
\text { extra storeys. }\end{array}$ & 60 million \\
\hline $\begin{array}{l}\text { Sports stadium. This block offers a state-of-the-art new rugby venue, including underground carpark with } \\
\text { room for } 2400 \text { cars. The block only becomes available in stage } 3 \text { ! }\end{array}$ & 1 billion \\
\hline $\begin{array}{l}\text { Major tourist attraction. This block offers a new flagship tourism attraction in the vein of the Guggenheim } \\
\text { museum, combining experience with design. The block only becomes available in stage } 3 !\end{array}$ & 300 million \\
\hline
\end{tabular}

that limited their opportunities. For instance, while Auckland council had developed a visionary document and benefitted from land ownership, their budget was much too modest to achieve the vision. Furthermore, they were held accountable by the larger public through two rounds of voting, meaning they needed to take general public opinion into account as well. Next, a library with game pieces was created, roughly consisting of three categories: currency, actions, and buildings. Access to game pieces was dependent on stakeholder groups and each game piece had a specified value/price for activation. Currency was only available to players performing the role of Auckland council or project developers. Similarly, the action "Demolition works", which could be used to clear existing structures at a cost of NZ\$100,000 was only available for these two stakeholder groups. Conversely, the action "Protest group", which could be activated if at least four players agreed and resulted in a development stop for one round, could only be accessed by the residential stakeholder groups (i.e., Wynyard Quarter residents, Residents of greater Auckland, Ngāti Whātua Ōākei, and Commercial operators). The largest part of the game catalog pertained to buildings which could only be constructed by the two stakeholder groups with financial resources. Table 2 offers a description of the building types that were made available.

\section{Stage 1: hit the lights}

At the start of the assignment, by way of introduction, the players needed to identify the different type of stakeholders in the game, since they had only been introduced to their own stakeholder group and scenario. Students were required to identify individual roles, think about potential alliances and map all stakeholders in terms of stakeholder influence via Mendelow's power-interest matrix (as cited in Pitt \& Koufopoulos, 2012). The introductory stage ended by collaboratively setting up the game board by identifying and constructing the buildings that already existed at 
the start of 2015. The situation of 2015 served as the starting point of the game since the redevelopment plan came into being at this point in time.

\section{Stage 2: I feel a change comin' on}

The second stage started with a brief presentation by the Auckland council players concerning the development vision over the next decades, and specifying priorities, urban functions, and transportation. Next, the project developers came forward with a conceptual development idea for the signature public building at tank farm, proposing a new sports venue and its associated advantages for different stakeholders. In the following public consultation round, the opposition had the chance to criticize the plans and suggest an alternative vision to try to convince voters in the later voting stage. Similarly, the wider public could have their opinion heard to try to alter the vision of the council. This round was followed by a building-round at which point Auckland council and the project developers, could add buildings (residential/offices/commercial) and public spaces to the map. In this stage, the potential signature public buildings were not yet available. The lecturer made sure that functional zoning and building regulations were respected. Residents had the option to start a protest against certain developments if agreement was found among at least four residents. At the end of stage 2, the public had to submit two votes: a vote for the current council or the opposition, and a vote in favor or against the stadium proposal. Note from Table 1 that the number of votes students were allowed to cast depended on their respective stakeholder role, in order to somewhat account for difference in population size.

\section{Stage 3: big city life}

If the council was voted out of office at the end of stage 2, the opposition would revert to being the ruling party and receive all the remaining council funds. Next, some time was given for the public administration to consult with the project developers to align their ideas based on the opinions heard in stage 2. A main decision to make at this stage concerned the feasibility of the stadium project and whether an alternative vision and development for the tank farm would need to be considered instead. This decision was then presented to the general public. The additional rounds in stage 3 followed a similar structure as the previous stage, namely: a consultation round, a building-round (at which point the potential signature public building had become available), and a final voting-round where a vote was placed for or against the current council and for or against the final realized development at the tank farm (i.e., stadium, major tourist attraction, or regular buildings/parks).

\section{The learning outcomes}

The learning activity was primarily seen as a formative exercise. In order to also allow for a summative component to the game itself, students were required to write a personal reflection on the learning experience achieved via the gamification. This followed the recommendations of Egenfeldt-Nielsen (2005) that additional activities are required to encourage reflective observation and abstraction.

The primary learning outcome was to provide students with an additional level of understanding of the underlying power-relations in urban development plans. Via the game setup, students could better understand and apply stakeholder mapping and its subsequent effects on development-dynamics. Furthermore, through the various constraints placed on different players, students could develop insights into the complexities of comprehensive city planning, needing to link community needs with capital requirements and land use zoning. The gamification exercise was thereby also linked with the final course assessment in which students had to write a 
feasibility report on the urban development plans of Wynyard Quarter-covering the historic background and development goals, stakeholder mapping, an inventory of recreational and tourist facilities, an analysis of transportation characteristics, and a suggestion for a signature building and analysis of its impacts and building requirements.

Secondly, an important learning outcome was to offer students insights into novel available tools to collect different stakeholder views and transform areas through bottom-up planning and cooperation. From the student reflection, we could surmise that through the multiplayer game, planning and development became a multi-dimensional interaction and potential conflicts could better be understood prior to starting the actual building phase. Finally, learning outcomes involved the transformation of students from passive observers to active participants in the creative process of redeveloping city spaces. Rather than critiquing existing plans, students were challenged to think of alternatives and solutions by co-constructing knowledge.

\section{Recommendations}

A game should incorporate three main elements: goals, rules, and feedback systems (McGonigal, 2011). The goals and rules are set prior to the game and link back to the stakeholder profiles. While there is leeway in the amount of stakeholder groups, it is advisable to not raise the complexity of the game too much by keeping the number of stakeholders manageable. It is important that different stakeholders have different objectives and winning strategies. One challenging aspect is to allow for equal participation because by their very nature, not all stakeholders will have similar interest or hold similar power over the proceedings. This would provide a challenge in case the game wants to be used as a summative assessment and it is advisable to only link summative aspects to a post-game critical reflection.

While it is not necessary to link the game to an actual urban redevelopment project, such situations do serve to provide students with a realistic experience. In any case, the game works best when the area of the gameboard provides a semi-blank canvas (in our case a former industrialized area with significant open space). Urban areas that are already fully developed would complicate the building stage and limit the creative freedom of students. In terms of learning activity stages, while these could be extended (more than three) or limited (only two stages), it is recommended to offer at least three stages to allow for feedback moments during the exercise and adaptation of strategies by different players. As such, a minimum of $2 \mathrm{~h}$ is advisable for the game. Finally, our gamification-exercise was originally played by 30 students simultaneously and-in a second installment-repeated in two groups of approximately 15 players each. Unless the game map is enlarged, and multiple tutors are present, lower participant numbers (approximately 15 students) tend to increase participation and improve the learning experience.

\section{Conclusion}

Planning and large-scale (re)development of city spaces can have broad implications for numerous stakeholders, many of which do not have a direct voice in the planning process and lack political and financial power to significantly influence decision-making. Even under the best intentions, top-down planning and development often trigger negative externalities. Even though community participation is a cornerstone in the sustainable development debate, practical tourism planning processes often show ineffective stakeholder management at best, at least partly caused by the complexity of the tourist system. Such situations have, at times, led to negative community attitudes toward tourism development which ultimately influences the competitive position of a destination as a whole.

While public information and feedback moments are traditionally organized, novel approaches that have been experimented with involve gamification of reality, either via an online simulation 
or as a more traditional board game. Such techniques allow for the creation of a learning and sharing environment (Innes \& Booher, 2004), potentially improving resident empowerment (Boley et al., 2014). The learning activity described in this paper provided students with such an urban game experience. The game increased student engagement and supported understanding of stakeholder motivations, relationships, and strategies. Furthermore, it allowed students to familiarize themselves with new tools for community engagement, soliciting feedback, and co-creating new urban areas, which can be particularly helpful in terms of activating local, site-specific community knowledge (Van Herzele, 2004). In doing so, students are better equipped to understand development processes and create their own creative instruments for data collection and discussion moderation.

\section{ORCID}

Bart Neuts (D) http://orcid.org/0000-0002-6518-650X

\section{References}

1news (2016, November 11). 'The landmark of Auckland' - architect wants surf break and floating pitches next to new waterfront stadium. 1 news now. Retrieved from http://www.tvnz.co.nz.

Boyle, S. (2011). Teaching toolkit. An introduction to games based learning (UCD Teaching and Learning Resources, October 2011). Retrieved from http://www.ucd.ie/teaching.

Boley, B. B., McGehee, N. G., Perdue, R. R., \& Long, P. (2014). Empowerment and resident attitudes toward tourism: Strengthening the theoretical foundation through a Weberian lens. Annals of Tourism Research, 49, 33-50. doi:10.1016/j.annals.2014.08.005

Cooper, C., Scott, N., \& Baggio, R. (2009). Network position and perceptions of destination stakeholder importance. Anatolia, 20(1), 33-45. doi:10.1080/13032917.2009.10518893

Crossa, V. (2009). Resisting the entrepreneurial city: Street vendors' struggle in Mexico City's Historic Center. International Journal of Urban and Regional Research, 33(1), 43-63. doi:10.1111/j.1468-2427.2008.00823.x

Deterding, S., Dixon, D., Khaled, R., \& Nacke, L. (2011). From game design elements to gamefulness: Defining "gamification". Proceedings of the 15th International Academic MindTrek Conference: Envisioning future media environments, 9-15. New York, NY: Association for Computing Machinery. doi:10.1145/2181037.2181040

Dodds, R., \& Butler, R. (2010). Barriers to implementing sustainable tourism policy in mass tourism destinations. Tourismos, 5(1), 35-53. Retrieved from http://mpra.ub.uni-muenchen.de/25162/.

Egenfeldt-Nielsen, S. (2005). Beyond edutainment: Exploring the potential of computer games for education (Doctoral thesis). University of Copenhagen, Copenhagen, Denmark. Retrieved from http://education.ucf.edu/ insttech/docs/egenfeldt.pdf

Francis, R. (2006, March). Towards a theory of games based pedagogy. Paper presented at the JISC Innovating elearning: Transforming learning experiences conference, Online. Retrieved from http://www.online-conference. net/jisc/content/Francis\%20-\%20games\%20based\%20pedagogy.pdf

Getz, D., \& Timur, S. (2005). Stakeholder involvement in sustainable tourism: Balancing the voices. In W. Theobald (Ed.), Global tourism (3rd ed., pp. 230-247). Oxford, UK: Butterworth-Heinemann.

Hamilton, K., \& Alexander, M. (2013). Organic community tourism: A cocreated approach. Annals of Tourism Research, 42, 169-190. doi:10.1016/j.annals.2013.01.015

Han, H.-C. (2015). Gamified pedagogy: From gaming theory to creating a self-motivated learning environment in studio art. Studies in Art Education, 56(3), 257-267. doi:10.1080/00393541.2015.11518967

Innes, J. E., \& Booher, D. E. (2004). Reframing public participation: Strategies for the 21st century. Planning Theory \& Practice, 5(4), 419-436. doi:10.1080/1464935042000293170

Ioannides, D. (1995). A flawed implementation of sustainable tourism: The experience of Akamas, Cyprus. Tourism Management, 16(8), 583-592. doi:10.1016/0261-5177(95)00081-X

Jaffe, L. (2007). Games amplify motivation in education. In M. J. Bradshaw, \& A. J. Lowenstein (Eds.), Innovative teaching strategies in nursing and related health professions (4th ed., pp. 161-172). Sudbury, MA: Jones and Bartlett Publishers.

Kolb, D. A. (1984). Experiential learning: Experience as the source of learning and development. London, UK: Prentice-Hall.

Loopmans, M., \& Marrécau, F. (2016). Omgeving op mensenmaat. Praktijkboek sociaal-ruimtelijke planning in West-Vlaamse dorpen en steden. Brugge, Belgium: Grafische Dienst Provincie West-Vlaanderen. 
McGonigal, J.. (2011). Reality is broken: Why games make us better and how they can change the world. New York, NY: Penguin Books.

Neuts, B., Devos, T., \& Dirckx, T. (2014). Turning off the red lights: Entrepreneurial urban strategies in 'De Wallen' Amsterdam. Applied Geography, 49, 37-44. doi:10.1016/j.apgeog.2013.09.005

Orsman, B. (2017, March 11). Waterfront stadium back on cards after Goff launches feasibility study. New Zealand Herald. Retrieved from http://www.nzherald.co.nz.

Pitt, M. R., \& Koufopoulos, D. (2012). Essentials of strategic management. London, UK: Sage.

Reuschke, D. (2002). Public-Private Partnerships in urban development in the United States (Wirtschaftsuniversität Wien, Working paper). Retrieved from http://www-sre.wu-wien.ac.at/neurus/reuschke.pdf.

Ripp, M., \& Rodwell, D. (2018). Governance in UNESCO World Heritage Sites: Reframing the role of management plans as a tool to improve community engagement. In S. Makuvaza (Eds.), Aspects of management planning for cultural world heritage sites (pp. 241-253). Cham, Switzerland: Springer International Publishing.

Schofield, P. (2011). City resident attitudes to proposed tourism development and its impacts on the community. International Journal of Tourism Research, 13(3), 218-233. https://doi-org.kuleuven.ezproxy.kuleuven.be/10. 1002/jtr.814. doi:10.1002/jtr.814

Tan, E. (2014). Negotiation and design for the self-organizing city (Gaming as a method for urban design (Doctoral thesis). Dehisce Universities' Delft, Delft, the Netherlands. Retrieved from https://journals.open.tudelft.nl/index. $\mathrm{php} / \mathrm{abe} / \mathrm{issue} / \mathrm{view} / 384$.

The New London Group. (1996). A pedagogy of multiliteracies: Designing social futures. Harvard Educational Review, 66(1), 60-92. doi:10.17763/haer.66.1.17370n67v22j160u

Van Herzele, A. (2004). Local knowledge in action: Valuing nonprofessional reasoning in the planning process. Journal of Planning Education and Research, 24(2), 197-212. doi:10.1177/0739456X04267723

Waligo, V., Clarke, J., \& Hawkins, R. (2015). Embedding stakeholders in sustainable tourism strategies. Annals of Tourism Research, 55, 90-93. doi:10.1016/j.annals.2015.09.002

Waterfront Auckland. (2012). The Waterfront Plan 2012. Retrieved from https://www.panuku.co.nz/www/uploads/ moduleresourceitems/the-waterfront-plan-2012-9e08935901.pdf. 